Click www.researchjournal.co.in/online/subdetail.html to purchase.

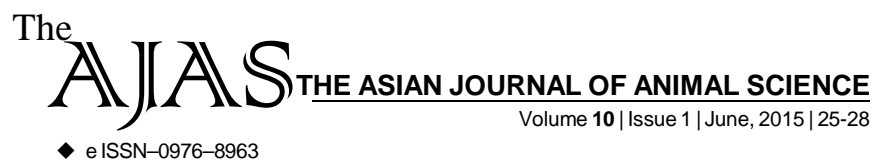

DOI : 10.15740/HAS/TAJAS/10.1/25-28 Visit us | www.researchjournal.co.in $\mathrm{S}$.

RESEARCH ARTICLE.

\title{
Studies on some common adulterants in the milk sold in Kanpur
} City

RAMJEE GUPTA AND P.K. UPADHYAY

Author for Corresponding -

\section{RAMJEE GUPTA}

Department of Animal

Husbandry and Dairying, C.S.A.

University of Agriculture and

Technology, KANPUR (U.P.) INDIA

See end of the article for

Coopted authors'
ABSTRACT...... The problem of adulteration of milk in Kanpur city is a burning problem now a days. The present study was planned for the detection of nature and extent of adulteration practiced in milk supply by the different agencies of Kanpur city. The study was conducted in the month of March - April 2010. In different agencies i.e., University dairy farm, Amul dairy, Parag dairy vendors and halwais milks. The milk samples were analysed for colours appearance, flavour, specific gravity, fat, total solid, S.N.F., pond water, starch, sodium-bicarbonate, urea and detergent powder are observed the present investigation. The maximum physical quality is observed in Amul Dairy, Maximum specific gravity was noted in Amul Dairy, highest fat and total solid, S.N.F., starch, sodium bicarbonate in Halwais milk, pond water, detergent powder, urea- Rawatpur market. It is also concluded that milk samples obtained from Amul dairy and Parag dairy were free from adulteration. It is suggested that Government should adopt all possible steps to check the fraudulent adulteration practices being used in the milk business. The milk samples collected from Rawatpur market had the maximum (50\%) detergent powder positive, whereas the samples collected from Govind Nagar market had minimum (16.67\%). On an average the milk supplied in Kanpur city found (33.33\%) detergent powder. However, none of the samples were found to be detergent powder positive i.e., Amul dairy, Parag dairy and university dairy Kanpur.

KEY WORDS....... Adultereted milk, Synthetic milk, Amul dairy, Adulterants in the milk

HOW TO CITE THIS ARTICLE - Gupta, Ramjee and Upadhyay, P.K. (2015). Studies on some common adulterants in the milk sold in Kanpur City. Asian J. Animal Sci., 10(1) : 25-28.

ARTICLE CHRONICLE - Received : 06.06.2014; Revised : 14.04.2015; Accepted : 29.04.2015 